\title{
Natural enemies associated to aphids in peach orchards in Araucária, Paraná, Brazil
}

\author{
Schuber, JM. ${ }^{a *}$, Monteiro, LB. ${ }^{a}$, Almeida, LM. ${ }^{b}$ and Zawadneak, MAC. ${ }^{c}$ \\ a'Departamento de Fitotecnia e Fitossanitarismo, Universidade Federal do Paraná - UFPR, \\ Rua dos funcionários, 1540, CEP 80035-050, Curitiba, PR, Brazil \\ bDepartamento de Zoologia, Universidade Federal do Paraná - UFPR, Centro Politécnico, \\ Jardim das Américas, s/n, CEP 81531990, Curitiba, PR, Brazil \\ ${ }^{\mathrm{c}}$ Departamento de Patologia Básica, Centro Politécnico, Universidade Federal do Paraná - UFPR, \\ Jardim das Américas, s/n, CEP 81531990, Curitiba, PR, Brazil \\ *e-mail: joseliaschuber@yahoo.com.br
}

Received September 23, 2011 - Accepted January 26, 2012 - Distributed November 30, 2012

(With 1 figure)

\begin{abstract}
Natural enemies of the Class Insecta are important agents in the balance of aphid populations and an alternative to using insecticides to control these insects. The aim of this study was to identify the species of natural enemies associated with aphids present in peach orchards and observe the efficiency of capturing different sampling methods. The experiment was conducted from July, 2005 to September, 2006 in six peach orchards 'Chimarrita', in Araucária, PR, Brazil. The samples were taken by visual analysis in peach plants and weeds, yellow pan traps, sticky traps and funnels. Predator species were identified: Cryptolaemus montrouzieri, Cycloneda pulchella, Cycloneda sanguinea, Eriopis connexa, Harmonia axyridis, Hippodamia convergens and Scymnus sp. (Coleoptera, Coccinellidae), Allograpta sp., Palpada sp. and Toxomerus sp. (Diptera, Syrphidae) and Chrysoperla sp. (Neuroptera, Chrysopidae) and the parasitoids: Diaretiella rapae, Opius sp. and Praon sp (Braconidae). Examples of Encyrtidae and Eulophidae await identification. Chrysoperla sp. was a less abundant species. There were no statistically significant differences between the different sampling methods tested.
\end{abstract}

Keywords: aphids, insecta, parasitoids, predators, traps.

\section{Inimigos naturais associados a afídeos em pomares de pessegueiros em Araucária, Estado do Paraná, Brasil}

\section{Resumo}

Os inimigos naturais da Classe Insecta são importantes agentes no equilíbrio das populações de afídeos e uma forma alternativa ao uso de inseticidas no controle desses insetos. O objetivo deste estudo foi identificar as espécies de inimigos naturais associados aos afídeos presentes em pomares de pessegueiros, além de verificar a eficiência de captura de diferentes métodos de amostragem. O experimento foi realizado de julho de 2005 a setembro de 2006 , em seis pomares de pessegueiros 'Chimarrita' em Araucária-PR, Brasil. As amostragens foram realizadas por meio de: análise visual em plantas de pessegueiros e plantas invasoras; armadilhas amarelas; armadilhas adesivas, e funil. Foram identificados os predadores: Cryptolaemus montrouzieri, Cycloneda pulchella, Cycloneda sanguinea, Eriopis connexa, Harmonia axyridis, Hippodamia convergens, Scymnus sp. (Coleoptera, Coccinellidae), Allograpta sp., Palpada sp., Toxomerus sp. (Diptera, Syrphidae) e Chrysoperla sp. (Neuroptera, Chrysopidae), além dos parasitoides: Diaretiella rapae, Opius sp. e Praon sp. (Braconidae). Exemplares de Encyrtidae e Eulophidae aguardam identificação. Chrysoperla sp. foi a espécie menos abundante. Não foram constatadas diferenças estatísticas significativas entre os diferentes métodos de amostragem testados.

Palavras-chave: afídeos, insecta, parasitoides, predadores, armadilhas.

\section{Introduction}

For successful pest control using natural enemies, it is essential to identify pest species and beneficial organisms correctly, which are present in the culture. Based on the knowledge of the species, the insect's population, the possible damage to pests and the potential of controlling natural enemies should be monitored (Altieri et al., 2005; Guedes et al., 2000). Depending on the orchard peach Prunus persica (L.) Batsch area, aphids can appear, 
which colonize both crops and weeds (Ilharco, 1992), and the continuous sucking of phloem sap from the shoots affect the formation of the branch due to the wizened and deformed leaves (Taiz and Zeiger, 2004). Populations of aphids can be reduced naturally when natural enemies are present, which can be an alternative to using chemicals (Cardoso and Lazzari, 2003). The insects that act in the biological control of aphids belong to the families: Coccinellidae (Coleoptera) (Obrycki and Kring, 1998), Syrphidae (Diptera) (Gonçalvez and Gonçalvez, 1976), Chrysopidae (Neuroptera) (Grasswitz and Burts, 1995) and Hymenoptera (Parra et al., 2002). The aim of this study was to identify the species of natural enemies associated with aphids present in peach orchards in Araucária, PR and evaluate the most efficient sampling method in capturing these natural enemies.

\section{Material and Methods}

The experiment was conducted from July, 2005 to September, 2006 in Araucária, Paraná State, Brazil $\left(25^{\circ}\right.$ $35^{\prime} 35^{\prime \prime} \mathrm{S}$ and $49^{\circ} 24^{\prime} 37^{\prime}$ ' W, altitude: $897 \mathrm{~m}$ ). The climate is mesothermal according to the Köppen classification, with an annual average temperature of $16{ }^{\circ} \mathrm{C}$, relative humidity of $80 \%$ and rainfall around $1,500 \mathrm{~mm}$ per year (Simepar, 2006). Six 'Chimarrita' peach orchards were selected, which were on average 0.44 ha and there were 150 plants, trained with four branches, spaced $6 \times 4 \mathrm{~m}$, with an average age of approximately eight years. Data concerning the aphid's natural enemies was collected from peach plants and weeds, with yellow traps, sticky boards and a funnel. Moreover, species were identified by experts.

Peach tree collection - In each orchard, five plants were chosen at random. To verify the presence of insects, leaves and branches were analysed on a weekly basis at a height of $1.70 \mathrm{~m}$ above the ground. The insects were collected using forceps, brushes, test tubes and were then packed in plastic containers, which were previously identified and labelled.

Invasive plant collection - In each orchard, three areas of $24 \mathrm{~m}^{2}$ located between lines were defined at random. The plants in these areas were inspected monthly to verify the presence of insects.

Yellow pan traps - Four traps $(29 \times 20 \times 6 \mathrm{~cm})$ were set up between the lines of each orchard, at an average height of $90 \mathrm{~cm}$ above the soil, containing 1.25 liters of water and $2 \mathrm{~mL}$ of neutral detergent to break the surface tension. The collected insects were removed on a weekly basis using a wash bottle, and transferred to plastic containers and the content of the traps was replaced.

Adhesive Plates - In each orchard, two peach trees were chosen randomly, and were placed in each of the trees at $1.70 \mathrm{~m}$ Bio Trap ${ }^{\circledR}$ high adhesive plates, from Bio Control $(24.5 \times 10 \mathrm{~cm})$ in yellow and blue. The plates were replaced monthly and the obtained insects were counted in the laboratory.

Funnel - Weekly, ten samples of peach plants were taken using this method. A metal funnel $(60 \mathrm{~cm}$ diameter top $\times 10 \mathrm{~cm}$ diameter $\times 40 \mathrm{~cm}$ height) was placed under the side branches and and the trees were hit three times using a stick. Samples were collected from September, 2005 to September, 2006, except for April to July 2006, the dormancy process of the peach trees.

Screening material - The collected material was transported to the laboratory where the insects were separated according to morphological characteristics to make it easier to identify species. They were counted and preserved in $70 \%$ ethyl alcohol. The aphid mummies were placed individually in gelatin capsules and packed in a controlled environment at a temperature of $25 \pm 2{ }^{\circ} \mathrm{C}$ at a relative humidity of $80 \pm 5^{\circ} \mathrm{C}$ and a photoperiod of 14 hours, until parasitoids emerged. The obtained insects were identified using identification keys, reference collections or specific articles and the species were later confirmed by experts.

Statistical analysis - Analysing dependent variables were carried out using analysis of variance in a completely randomized design. The dependent variables were compared using the multiple comparison Tukey test with a degree of reliability of $95 \%$.

\section{Results and Discussion}

By collecting natural enemies using different sampling methods, a wide range of species could be captured (Table 1). A total of 1,296 specimens of natural enemies were identified, and $57.2 \%$ were classified as predators represented by the Coccinellidae (26.5\%), Syrphidae (27.8\%) Chrysopidae $(2.9 \%)$ and $42.8 \%$ as parasitoids distributed in Braconidae (84.9\%), Eulophidae (9\%) and Encyrtidae (6.1\%). The families of predators found in this study corroborate those reported by Resende et al. (2006), who captured insect species of Coccinellidae, Chrysopidae and Syrphidae in kale (Brassica oleracea L. var. acephala D.C.) cultivated in the organic system.

Syrphidae flies belonging to the genus Palpada Macquart, 1834 (47.5\%, 2 morphospecies); Toxomerus Macquart, 1855 (35\%, 2 morphospecies) and Allograpta Osten Sacken, 1875 (17.5\%, 1 morphospecies) were collected (Table 1). The syrphids adults are pollinators, however few species present predatory larvae (Marinoni and Bonatto, 2002). The genus Palpada was the most collected in the peach trees orchards, occupying a dominant position among the Syrphidae species, which is according to studies by Machado and Loyola (2000), who collected this genus in Cordia multispicata (Boraginaceae) and Borreria alata (Rubiaceae) in a fragment of the Atlantic forest in Pernambuco State, northeastern Brazil; and Souza-Silva et al. (2001), who found the genus Palpada on flowers of Rhamnaceae, Boraginaceae and Asteraceae. The Syrphid species found in this study were also reported by Silva et al. (1968) developed in various regions of Brazil. Bartoszeck (1976) found the same species in plums (Prunus domestica L.) and peaches (P. persica) in Curitiba, PR, and Mendes et al. (2000) in alfafa in Lavras, MG. Gonçalvez and Gonçalvez (1976) observed species of the genera Allograpta and Ocyptamus Macquart, 1834 preying on aphids in various crops. Out of 


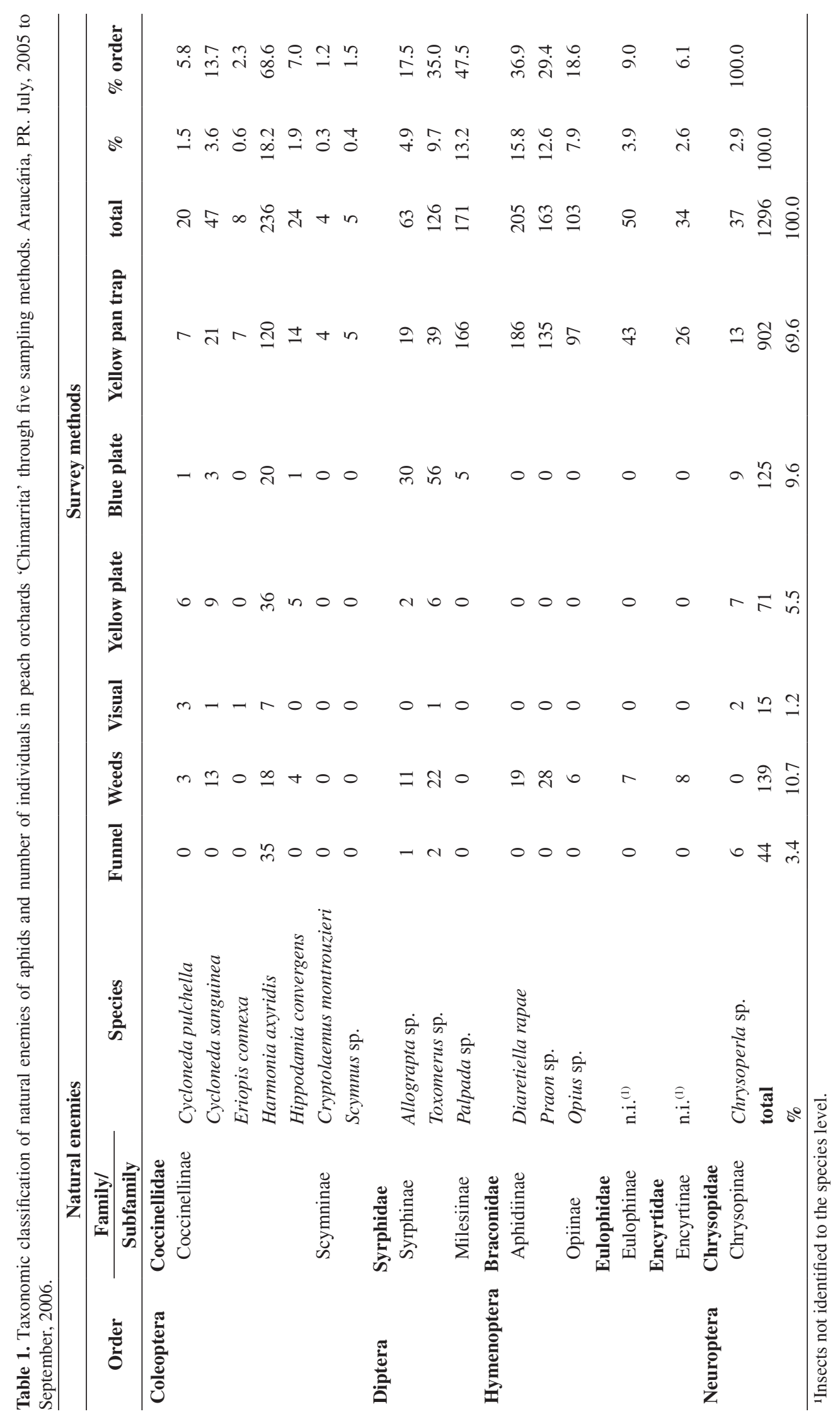


the 150 described species of Toxomerus, 140 occur in the Neotropical Region and the majority of Toxomerus species are predators of aphids. Moreover, their distribution and abundance are closely related to these insects (Metz and Thompson, 2001). In peach trees, in the mining region of Jacuí, Auad et al. (1997) found the genera Allograpta, Syrphus Fabricius, 1775, Ocyptamus and Pseudodoros Becker 1903. Allograpta exotic Wiedemann (1930) was the most collected by Lazzari (1985) in different regions of Parana State.

Coleoptera are represented by 344 specimens of the Coccinellidae: Harmonia axyridis (Pallas, 1773) $(68.6 \%)$; Cycloneda sanguinea (L., 1763) (13.7\%); Hippodamia convergens (Guerin, 1842) (7.0\%); Cycloneda pulchella (Klug, 1829) (5.8\%); Eriopis connexa Germar, 1824 (2.3\%); Scymnus Kugelann, 1794 (1.5\%) and Cryptolaemus montrouzieri Mulsant, 1853 (1.2\%) (Table 1). The number of species found in this study was higher than that found by Bartoszeck (1976) in Curitiba, PR, who observed coccinellids in plum trees $(P$. domestica) and peach trees (P. persica) associated with the aphid Brachycaudus (Appel) schwartzi (Börner, 1931). The species E. conexa, C. sanguinea, H. convergens, Scymnus (Pullus) argentinicus (Weise, 1906) were also found in peach trees by Auad et al. (1997) associated with the aphid B. schwartzi.

Among the coccinellids, $H$. axyridis was the most collected in peach orchards of Araucária, corroborating the observations made by Zawadneak (2006) in lettuce in Pinhais, PR. Although $H$. axyridis was considered an efficient predator of various species of aphids (Koch, 2005), studies should be conducted to observe their influence on the food chain (Zawadneak, 2006). It is an exotic insect that was first recorded in Brazil in 2002 (Almeida and Silva, 2002) and is predominant in many areas of study in Paraná (Almeida and Silva, 2002; Zawadneak, 2006). Koch (2005) cited coccinellid species that can feed on ripe fruit in Europe, such as peaches, contaminating them with their droppings. In North America, H. axyridis has been designated pest status (Koch, 2005), since it has the habit of invading houses in the colder seasons of the year, seeking shelter and food (Almeida and Silva, 2002).

Chrysoperla Steinmann, 1964 was the only genus of Chrysopidae (Neuroptera) collected. Despite the small number of individuals (37), the green lacewings exceeded the frequency of some coccinellid genus (Table 1). According to Tauber et al. (2000), lacewings are among the main agents of natural biological control, due to their high predatory capacity.

Braconidae (Ichneumonoidea), Encyrtidae and Eulophidae (Chalcidoidea) were the families of parasitoids, which were identified. The braconids obtained were: Opius Wesmael, 1835, Praon Haliday, 1833 and Diaeretiella rapae (Mc 'Intosh, 1855), and the last two were the most abundant. These wasps are endoparasitoids of adults and immature stages of several species of aphids (Stary, 1964). Specimens of Eulophinae and Encyrtinae were not identified at species level. The eulophids are parasitoids of a great variety of hosts, especially those on tissues of plants, such as miner larvae, gall formers and stem borers (Bittencourt and Berti Filho, 2004). Specimens of Alloxysta Foerster, 1869 (Hymenoptera: Figitidae) were collected. They are hyperparasitoids of the Aphididae (Hemiptera) and interrupt the chain of biological control of pests.

In this study, a total of 32 aphid species, belonging to 21 genera, were trapped. The species trapped with higher frequencies were: Uroleucon ambrosiae (Thomas, 1878), Brevicoryne brassicae (Linnaeus, 1758), Aphis spiraecola Patch (1914), Toxoptera citricida Kirkaldy (1907), Myzus persicae (Sulzer, 1776), Macrosiphum rosae (Linnaeus, 1758) and Aulacorthum solani Kaltenbach (1843). The other species occurred in frequencies below $1 \%$ (Schuber et al., 2009). This study also showed that Brachycaudus persicae (Passerini, 1860) is the only aphid species, which colonizes P. persica in Araucária, PR, Brazil and the occurrence of the other species in larger quantities may be related to the higher diversity of families of weeds in the orchards (Schuber et al., 2009). There were no statistically significant differences when comparing different sampling methods tested (Figure 1). However, for catching the syrphids, the yellow pan trap was more efficient because it collected $62.2 \%$ of the total specimens, while the blue sticky traps collected $25.3 \%$ and the samples in the invasive plants $9.2 \%$. These results confirm the observations of Guajará et al. (2004), who observed that Syrphidae were attracted by the yellow color of the sticky traps. The samples with the funnel, the yellow sticky cards and visual collections accounted for $3.3 \%$ of the syrphids collected.

The largest number of coccinellids was obtained using yellow pan traps $(51.7 \%)$, and yellow sticky traps (16.3\%). The other sampling methods captured $32.0 \%$. Resende et al. (2006) captured 17 species of Coccinellidae from kale plants using the yellow sticky traps method. According to Dowell and Cherry (1981), the yellow sticky traps are more efficient in coccinellid collections than the visual method; Civolani and Pasqualini (2003) reported that the manual collection method is more efficient than using yellow sticky traps to monitor aphids.

The largest number of specimens of crisopids (13 / $35.1 \%$ ) was obtained using yellow pan traps, $24.3 \%$ and $18.9 \%$ for blue and yellow sticky traps, respectively, $16.2 \%$ using funnels and $5.4 \%$ by collection in peach trees.

The parasitoids were mostly collected using yellow pan traps $(87.7 \%)$, the remainder obtained from aphid mummies present in invasive plants and peachtrees $(12.3 \%)$. The other sampling of methods (funnel, visual collection and in weeds and peach trees) did not capture specimens of parsitoids. The sticky traps captured hymenopterans, but the individuals were not included because of the difficulty in removing these insects intact from the glue, which made it impossible to identify.

It is worth mentioning the difficulty of the taxonomic study of parasitoids due to the diversity of specimens caught using the yellow pan traps, while collecting mummies in colonies of aphids enabled us to obtain parasitoids that acted effectively in terms of controlling these insects. Major developments in research with this 


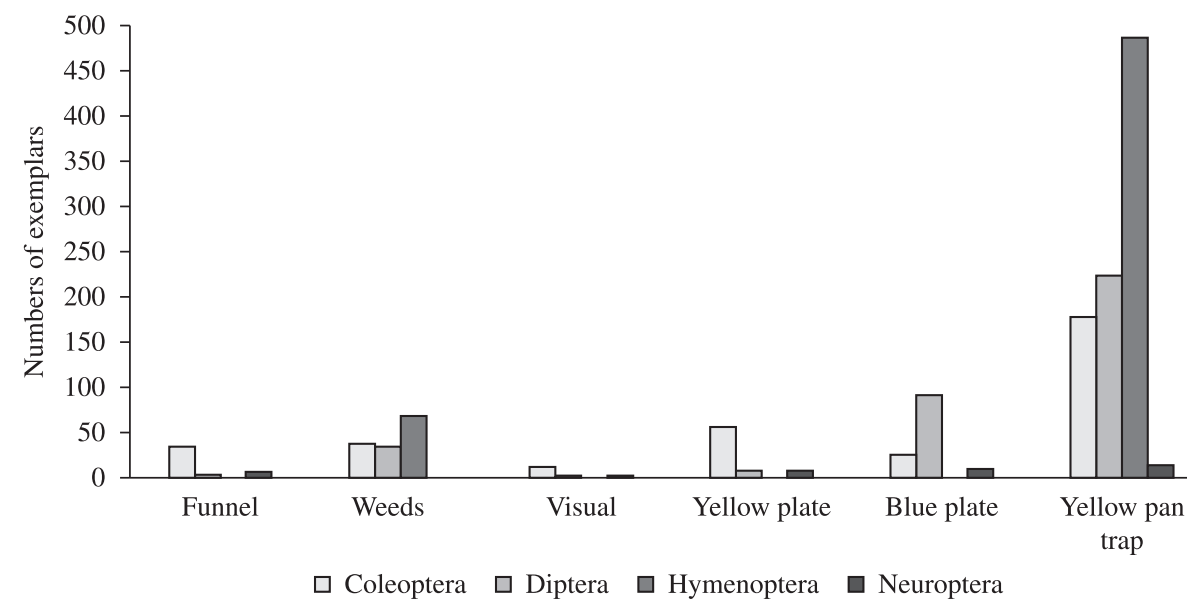

Figure 1. Total of Coleoptera, Diptera, Hymenoptera and Neuroptera captured in peach orchards 'Chimarrita' through five sampling methods. Araucária, PR. July 2005 to September 2006.

group of natural enemies is very important, because the parasitoids play an essential role in maintaining ecological balance, contributing to the diversity of other organisms (Scatolini and Penteado-Dias, 1997).

Acknowledgements - To Ana Paula da Silva Loffredo and Profa. Dra. Angelica Maria Penteado Dias Martins, Universidade Federal de São Carlos (UFSCar) for the identification of the Braconidae. To Mirian Morales Nunes, Federal University of Parana (UFPR) for the identification of genus of the Syrphidae and the National Council of Scientific and Technological Development (CNPq) for scholarship.

\section{References}

ALMEIDA, LM. and SILVA, VB., 2002. Primeiro registro de Harmonia axyridis (Pallas) (Coleoptera: Coccinellidae): um coccinelídeo originário da região Peleártica. Revista Brasileira de Zoologia, vol. 19, p. 941-944.

ALTIERI, M., NICHOLLS, C. and FRITZ, MA., 2005. Manage insects on your farm: a guide to ecological strategies. Beltsville: Sustainable Agriculture Network. 130 p.

AUAD, AM., BUENO, VHP., KATO, CM. and GAMARRA, DC., 1997. Ocorrência e flutuação populacional de predadores e parasitóides de Brachycaudus (Appelia) schwartzi (Börner) (Homoptera: Aphididae), em pessegueiros, em Jacuí, MG. Anais da Sociedade Entomológica do Brasil, vol. 26, p. 257-263.

BARTOSZECK, AB., 1976. Afídeos da ameixeira (Prunus domestica) e pessegueiro (Prunus persica), seus predadores e parasitas. Acta Biológica Paranaense, vol. 5, no. 1-2, p. 69-90.

BITTENCOURT, MAL. and BERTI FILHO, E., 2004. Development of immature stages of Palmistichus elaeisis Delvare \& LaSalle (Hymenoptera, Eulophidae) in Lepidoptera pupae. Revista Brasileira de Entomologia, vol. 48, p. 65-68.

CARDOSO, JT. and LAZZARI, SMN., 2003. Comparative biology of Cycloneda sanguinea (Linnaeus, 1763) and Hippodamia convergens Guérin-Méneville, 1842 (Coleoptera: Coccinellidae) focusing on the control of Cinara spp. (Hemiptera: Aphididae).
Revista Brasileira de Entomologia, vol. 47, p. 443-446. http:// dx.doi.org/10.1590/S0085-56262003000300014

CIVOLANI, S. and PASQUALINI, E., 2003. Cacopsylla pyri L. (Homoptera: Psyllidae) and its predators relationships in Italy's Emilia-Romagna region. Journal of Applied Entomology, vol. 127, p. 214-220.

DOWELL, RV. and CHERRY, RH., 1981. Survey traps for parasitoids, and coccinellid predators of the citrus blackfly, Aleurocanthus woglumi. Entomologia Experimentalis et Applicata, vol. 29, p. 356-362. http://dx.doi.org/10.1111/j.1570-7458.1981. tb03079.x

GONÇALVEZ, CR. and GONÇALVEZ, AJL., 1976. Observações sobre moscas da família Syrphidae, predadoras de homópteros. Anais da Sociedade Entomológica do Brasil, vol. 5, p. 3-10.

GRASSWITZ, TR. and BURTS, EC., 1995. Effect of native natural enemies and augmentative releases of Chrysoperla rufilabris Burmeister and Aphidoletes aphidimyza (Rondani) on the population dynamics of the green apple aphid, Aphis pomi DeGeer. International Journal of Pest Management, vol. 41, p. 176-183. http://dx.doi.org/10.1080/09670879509371945

GUAJARÁ, M., CARVALHO, AG., SANTOS, W. and GONÇALVES, K., 2004. Resposta de Euphalerus clitoriae (Hemiptera: Psyllidae) às armadilhas adesivas de diferentes cores. Revista Árvore, vol. 28, p. 117-120. http://dx.doi.org/10.1590/ S0100-67622004000100015

GUEDES, JC., COSTA, ID. and CASTIGLIONI, E., 2000. Bases e técnicas do manejo de insetos. Santa Maria: Pallotti. 234 p.

ILHARCO, FA., 1992. Equilíbrio biológico de afídeos. Lisboa: Fundação Calouste Gulbenkian. 303 p.

KOCH, RL., 2005. The multicolored Asian lady beetle, Harmonia axyridis: a review of its biology, uses in biological control, and non-target impacts. Journal of Insect Science, vol. 3, p. 1-16.

LAZZARI, SN., 1985. Inimigos naturais dos afídeos (Homoptera, Aphididae) da cevada (Hordeum sp.) no Paraná. Anais da Sociedade Entomológica do Brasil, vol. 14, p. 5-15.

MACHADO, IC. and LOIOLA, MI., 2000. Fly pollination and pollinator sharing in two species: Cordia multispicata (Boraginaceae) 
and Borreria alata (Rubiaceae). Revista Brasileira de Botânica, vol. 23, p. 305-311.

MARINONI, L. and BONATTO, SR., 2002. Sazonalidade de três espécies de Syrphidae (Insecta, Diptera) capturadas com armadilha de Malaise no Estado do Paraná, Brasil. Revista Brasileira de Zoologia, vol. 19, p. 95-104. http://dx.doi.org/10.1590/S010181752002000100007

MENDES, S., CERVIÑO, MN., BUENO, VHP. and AUAD, AM., 2000. Diversidade de pulgões e de seus parasitóides e predadores na cultura da alfafa. Pesquisa Agropecuária Brasileira, vol. 35, p. 1305-1310. http://dx.doi.org/10.1590/ S0100-204X2000000700003

METZ, MA. and THOMPSON, FC., 2001. A revision of the larger species of Toxomerus (Diptera: Syrphidae) with description of a new species. Studia Dipterologica, vol. 8, p. 225-256.

OBRYCKI, JJ. and KRING, TJ., 1998. Predaceous Coccinellidae in biological control. Annual Review of Entomology, vol. 43, p. 295-321. PMid:15012392. http://dx.doi.org/10.1146/annurev. ento.43.1.295

PARRA, JRP., BOTELHO, PSM., CORREAA-FERREIRA, BS. and BENTO, JMS., 2002. Controle Biológico no Brasil: parasitóides e predadores. São Paulo: Manole. 635 p

RESENDE, ALS., SILVA, EE., SILVA, VB., RIBEIRO, RLD., GUERRA, JGM. and AGUIAR-MENEZES, EL., 2006. Primeiro registro de Lipaphis pseudobrassicae Davis (Hemiptera: Aphididae) e sua associação com insetos predadores, parasitóides e formigas em couve (Cruciferae) no Brasil. Neotropical Entomology, vol. 35, p. 551-555. PMid:17061806.

SCATOLINI, D. and PENTEADO-DIAS, AM., 1997. Fauna de Braconidae (Hymenoptera) como bioindicadora do grau de preservação de duas localidades do Estado do Paraná. Revista Brasileira de Ecologia, vol. 1, p. 84-87.

SCHUBER, JM., MONTEIRO, LB., POLTRONIERI, AS., CARVALHO, RCZ. and ZAWADNEAK, MAC., 2009. Population fluctuation and faunal indices of aphids (Hemiptera, Aphididae) in peach orchards in Araucária, PR. Brazilian Journal of Biology, vol. 69 , no. 3, p. 943-949. PMid:19802456.

SILVA, AGA., GONÇALVES, CR., GALVÃO, DM., GONÇALVES, AJL., GOMES, J., SILVA, MN. and SIMONI, ML., 1968. Quarto catálogo dos insetos que vivem nas plantas do Brasil: seus parasitos e predadores. Rio de Janeiro: Ministério da Agricultura. $622 \mathrm{p}$.

Sistema Meteorológico do Paraná - SIMEPAR, 2006. Tecnologia e Informações Ambientais. Available from: <http://www.simepar. br/>. Access in: 30 out. 2006.

SOUZA-SILVA, M., FONTENELLE, JCR. and MARTINS, RP., 2001. Seasonal abundance and species composition of flowervisiting flies. Neotropical Entomology, vol. 30, p. 351-359. http:// dx.doi.org/10.1590/S1519-566X2001000300002

STARY, P., 1964. Food specificity in the Aphidiidae (Hymenoptera). Entomophaga, vol. 9, p. 91-99. http://dx.doi.org/10.1007/BF02375744

TAIZ, L. and ZEIGER, E., 2004. Fisiologia Vegetal. 3. ed. Porto Alegre: Artmed Editora. 719 p

TAUBER, MJ., TAUBER, CA., DAANE, KM. and HAGEN, KS., 2000. Commercialization of predator: recent lessons from green lacewings (Neuroptera: Chrysopidae: Chrysoperla). American Entomologist, vol. 46, p. 26-34.

ZAWADNEAK, MAC., 2006. Artrópodos e moluscos em dois cultivares de alface. Curitiba: Universidade Federal do Paraná. 128 p. Tese de Doutorado em Produção Vegetal. 